\title{
Corpus Linguistic Analysis of the Connotative Meaning of Some Terms Used in the Context of 'The War on Terror'
}

\author{
Alaa Ghazi Rababah ${ }^{1,2}$ \\ ${ }^{1}$ Ph.D student at English Department, The University of Jordan, Amman, Jordan \\ ${ }^{2}$ English Instructor at English Department, Al Balqaa’ Applied University/ Princess Alia University College, \\ Amman, Jordan \\ Correspondence: Alaa Ghazi Rababah, English Department Al Balqaa' Applied University/ Princess Alia \\ University College, Amman, Jordan. E-mail: alaarababa@yahoo.com
}

Received: November 11, 2014 Accepted: December 22, $2014 \quad$ Online Published: January 27, 2015

doi:10.5539/ijel.v5n1p113 URL: http://dx.doi.org/10.5539/ijel.v5n1p113

\begin{abstract}
The study mainly examines the connotative meaning of several terms that are frequently used in the media in the political discourse of the September $11^{\text {th }}$ attacks and the 'War on Terror'. Eight items were identified which are 'Sunni', 'jihad', 'Islamist', 'fatwa', 'terrorism', 'radicalism', 'militant' and 'fundamentalism'. The study explores the existence of these terms in the Corpus of Contemporary American English in terms of the frequency of the selected terms, collocations and collocation patterns over two periods of time: ten years before and after the September $11^{\text {th }}$ attacks. The results of the study revealed that the frequency of these terms had remarkably increased after September $11^{\text {th }}$ and their conceptual meaning had been colored with new connotations.
\end{abstract}

Keywords: lexical change; denotations; collocations, connotations and frequency; corpus linguistic analysis

\section{Introduction}

\subsection{Historical Background}

Throughout history, the English language has expanded tremendously in its vocabulary. Such an expansion takes place within the process of 'lexical change' which can be viewed as part of the more general phenomenon of 'language change'. This process involves the creation of new lexical items (neologisms), borrowing of new foreign ones, the revival of old ones, a change in the use or meaning of an item, lexical loss and replacement (Durrie \& Ross, 1996, p. 276) (Grezega \& Schoner, 2007, p. 23 cited in Rababah, 2008, p. 9).

In times of peace, many events and socio-cultural factors in the history of English like empirical expansion, trade, travel and scholarly activities resulted in the introduction of new lexical items in the language. For example, during the Renaissance many new words from Greek and the Romance languages found their way into English. The expansion of the British Empire in America (1607), India (1610), Africa (1770) and Australia led to a further expansion in English vocabulary caused by the adoption of foreign lexical items related to the language and culture of those colonized countries (Hickey, 2004, pp. 621-626 cited in Taha, 2006, p. 86). Similarly, in war times and political turmoil, many new lexical items were added to English and others acquired new meanings and connotations. For instance, during the First and Second World Wars, many words and terms found their way into English and many old words were revived and used with a new military sense. 'Air raid', 'anti-aircraft gun', 'tank' and 'blimp' are all military terms that came into English between 1914 and 1918 as a consequence of the First World War (Baugh \& Cable, 1993, p. 295). In addition, the connotative meaning of some words was affected. During the Second World War, the word 'axis', a neutral geometric term, was transferred to the political sphere and given new connotations. It was adopted for the alliance of Germany and Italy in 1936. Identifying those who opposed the 'allies', the word came to carry a negative connotation. In contrast, the term 'allies' which is a neutral word meaning 'associate, kinsman,' or related to 'alloy' 'something bound up' came to resonate positively as it was used in reference to the 'Allied power' (Minkova \& Stockwell, 2001, p. 161). Other foreign words were loaned into English. During the Second World War, German terms like 'blitzkrieg', 'flack', and 'panzer' (armor) entered English (Partridge, 1948, pp. 123-124 cited in Rababah, 2008, p. 41). Other terms taken from French and Russian are respectively 'Maquis' referring to those French guerrilla fighters who opposed the Nazis in rural 
France and 'molotov bread-basket', a rack filled with bombs that is released from an aircraft (Baugh \& Cable, 1993, p. 294).

In recent years, many political incidents like the September $11^{\text {th }}$ attacks and other subsequent related events like the War in Afghanistan (2001) and Iraq (2003) led to other lexical changes in English. No doubt, the effect of the attacks and what is called the 'War on Terror' on the English language is undeniable. After the attacks, the media with its different outlets began describing and debating the events and the years of conflict that followed. This gave prominence to many terms which came to resonate with new meanings and connotations. For example, many old Arabic loanwords like 'jihad' and 'Islamist' were resurrected and given new meanings and connotations. Similarly, other old English terms like 'ground zero' were also revived and given a new meaning. The term 'ground zero' was first used to refer to the devastation caused by the atomic bombings of Hiroshima and Nagasaki. However, after the September 11th attacks, the term was used to describe the former site of the World Trade Center in New York City, which was destroyed by the attacks (Safire, 2001, cited in Rababah, 2008, pp. 51-52). Moreover, other English terms and phrases already existing in the language like 'terrorism' was given renewed recognition and also acquired new connotations.

\subsection{Objectives}

The main aim of this study is to analyze the connotative meaning of those politically and religiously oriented terms that have recently gained new prominence in different media outlets due to their repeated use in connection with the September $11^{\text {th }}$ attacks and as a main part of the 'War on Terror' discourse. This period (ten years after the September $11^{\text {th }}$ attacks) was chosen because it is bound in important political changes and events. It saw the rise of the two wars in Iraq and Afghanistan that largely attracted political and academic attention. The study is primarily concerned about examining collocations using the Corpus of Contemporary American English (COCAE) to uncover the semantic prosody that each one of the investigated terms has. In addition, the study traces the gradual sense development of each one of these terms in the history of English.

\subsection{Theoretical Background}

The different examples of lexical changes in the history of English presented previously in this study show that as part of 'lexical change', sometimes the meaning of words may undergo a change. This change in meaning is known as 'semantic change'. As it can be noted from some of these examples (e.g., axis), some words may develop new associative meanings in addition to their original conceptual meaning. Hence, it is worth distinguishing at this point between two types of meaning. The first is the conceptual or denotative meaning which simply refers to what a word denotes or stands for in the real world, that is, the word's referents. Put it in another way, it is the direct or dictionary meaning of a word. The second is the connotative meaning which constitutes the emotional implications and associations that a word may suggest in addition to its denotative meaning (Beard, 2004, p. 94). This type of meaning can be subdivided into collocative meaning which arises through association with words that tend to occur in the environment of another word. In other words, a collocative meaning of a word is one that a word acquires based on the meanings of words which tend to occur in its vicinity (Leech, 1975, p. 26) (Chimombo \& Roseberry, 1998, p. 117). Accordingly, semantic change can be looked at via 'denotative' (conceptual) and associative (connotative) meaning. Many studies were conducted by linguists to determine the ways through which these associative and denotative meaning can be added, removed or altered over time. Such ways are referred to as types of semantic change. The most widely recognized types of semantic change are extension, restriction, amelioration, pejoration and semantic shift (Minkova \& Stockwell, 2001, p. 156). An extension occurs when a word acquires a new additional meaning or its meaning becomes more general. A restriction of meaning, on the other hand, takes place when a word loses one of its meanings or its meaning becomes less general (ibid). While restriction and extension represent a change in the scope of a word's meaning, pejoration and amelioration involve changes in the value or status of the referents of a word. Pejoration occurs as a word develops negative meanings or loses positive ones. Amelioration, on the other hand, occurs as a word loses negative meanings or gains positive ones (Heller et al., 1984, p. 20). As for semantic shift, it takes place when a word loses an old meaning and develops a new one (ibid, p. 23). In short, the meaning of a word may completely change, expand or contract and in some cases when this happens it either ameliorates or pejorates. Such a change in word meaning, whether it is denotative or connotative, can be related to so many factors, for instance the context or the circumstances in which it is used.

Within this study the meaning change of the investigated terms will be examined in the light of the different circumstances and contexts surrounding the history of their use. However, more emphasis will be given on their current connotative meaning as the study mainly focuses in its analysis on the connotative collocative meaning of these terms using the COCAE. In fact, using corpus searches is very important to gain more insight into the 
connotative collocative meaning of words for they allow the researcher to study the words' most frequent collocates and so reveal their evaluative or associative meanings. Therefore, the results of such searches may confirm the intuitions or hypothesis proposed regarding the connotative meaning of a given word. Given this, words occur in collocations which show the associations and connotations they have. When some words appear regularly near another word and the relationship between them is statistically significant, such a co-occurrence is referred to as collocates (Baker, 2006, p. 96). However, when referring to the connotations and collocations, it is important to draw attention to the concept of 'semantic prosody'. This concept was first introduced by Bill Louw in 1993 and since then has become one of the most important concepts in corpus linguistics (Zhang, 2010, p. 190). Louw (1993) defined 'semantic prosody' as the 'consistent aura of meaning with which a form is imbued by its collocates'. Louw was enlightened by Firth's use of the term 'prosody' in phonology. Firth (1957) used 'prosody' to refer to "phonological colouring which spreads beyond semantic boundaries". For example, the word 'animal' has a strong nasal prosody because the vowel sound in ' $a$ ' is nasalized (having an additional nasal quality) because of being adjacent to the nasal sound of ' $n$ ' (ibid). Similarly, words share this feature of 'prosody' in lexical patterning. That is to say, they gain the same semantic features of their collocations. Further studies were made and more definitions were given on 'semantic prosody' by other linguists. Stubbs (1996) defines 'semantic prosody' as "a particular collocational phenomenon". He showed that the relationship between collocation and 'semantic prosody' is a matter of lexical selection. To illustrate this idea he referred to the verb 'provide' which collocates with some words like 'food', 'fund' and 'assistance' in the context of care, food and help to create positive prosody Besides this, he gave classifications of negative prosody, positive prosody and neutral prosody to 'semantic prosody' (Stubbs, 1996, p. 176 cited in Zhang, 2010, p. 191). Another definition of 'semantic prosody' is proposed by Partington (1998) who referred to the term as "the spreading of connotational coloring beyond single word boundaries" (68). He made the point that words spread certain connotations or prosodies through word boundaries that are similar in semantic feature to the meaning of the collocates of those words. For instance, the word 'rife' has a negative semantic prosody due to its co-occurrence with words such as 'crime', 'misery' and 'disease' (67).

In short, studying words' meanings cannot be done based on their individual meaning. Using words in a particular context creates an additional connotative collocative meaning which is sometimes referred to as 'semantic prosody'. Collocates can often indicate the 'semantic prosody' of a word. As Morely and Partington (2009) indicated semantic prosody resides 'in the collocational patterns of items in a text' (cited in Halbe, 2013, p. 80). Thus, a "word may be said to have a particular semantic prosody if it can be shown to co-occur typically with other words that belong to a particular semantic set" (Hunston \& Francis, 1993, p. 137, cited in Stewart, 2010, p. 13). In light of this, corpus collocate searches play a crucial role in revealing connotations or semantic prosodies of a given word.

\subsection{Literature Review}

Estrich and Sperber (1952) described semantic change in the light of psychological and emotional factors. In doing so, they offered a theory stating that some changes in meaning occur because of emotional pressure. Two words from the political history of English that developed new meanings during the American Civil War were studied and analyzed in depth to illustrate this theory. These are 'loco-foco' and 'copperhead'. They showed how 'loco-foco' had an overnight change of meaning from a name of a match to the name of a political party and in a similar process, 'copperheads' changed from a name of a venomous snake to that of a political party. They related this sudden change of meaning to emotional pressure resulting from the tensed political situation created during the American Civil War. According to them, the emergence of the first creative use of the two words with new meanings within such a situation contributed to their wide acceptance by the speech community. Hence, emotional and psychological factors play an important role in the whole process of change.

Leith (1997) examined the sense development of some words related to social power in English. He stated that the vocabulary of power and status, terms of address and words which refer to women are socially sensitive. In his view, such words used in reference to women and other minor and less powerful social groups are particularly sensitive to the development of pejorative and affective meaning and in opposition, those denoting the more powerful groups are most likely to retain an elevated meaning.

Taha (2006) studied the connotation of some Arabic loanwords that are frequently used in the context of the war in Iraq by examining college students' evaluations towards these loans. To study such evaluations, a questionnaire was administered to random samples of American students in the faculty of arts and sciences at Florida A\&M University in which they were asked to choose from a likert type scale the level of negativity or positivity with which they perceive each term. The analysis of questionnaire's results revealed that most of the students perceived the borrowings negatively. 
Rababah (2008) studied the effect of newspapers on semantic change. Her study discusses the powerful role of newspapers in influencing public perceptions mainly through the use of semantic change. It shows how newspapers succeeded in activating the semantic shift of the words 'terrorism' and 'fundamentalism' by restricting their meaning towards Arabs and Muslims. Moreover, the study examines the connotative meaning of some terms that gained wide circulation in the aftermath of the September $11^{\text {th }}$ attacks and the extent to which those connotations were influenced by the degree and frequency of exposure to the terms through reading them in newspapers. This was done by distributing a questionnaire to native speakers of English to study their evaluation of these terms and draw a correlation between the level of negativity with which each term is perceived and the degree and frequency of exposure to the terms through reading them in newspapers.

\section{Data Collection and Methodology}

The study adopts both a quantitative and qualitative method to examine the connotative meaning of the investigated terms. The researcher first conducted a pilot study to survey the most frequent terms used by Western journalists in connection with the September $11^{\text {th }}$ attacks. Sixteen items were included in the survey (see Appendix A). These items were subdivided into two groups; one group of words of Arabic origin and another of words of English origin. The researcher then ran a search for these surveyed items in the Corpus of Contemporary American English (COCA) to identify the top four terms from each group based on the frequency of occurrence of each in that corpus getting the total number of eight terms. The choice of this corpus is related to its large size. It is composed of more than 450 million words. The source of these words comes from more than 160,000 texts. The texts included in this corpus fall into five genres: spoken, fiction, magazines, newspapers and academic journals. The 450 million words in the corpus are divided evenly between these different types of genres (Davis, 2008). In fact, this reveals accurate changes in the language such as changes in meaning.

The frequency of each term was further examined over two different periods of times: ten years before and after September $11^{\text {th }}$, more particularly between the years 1990-2000 and 2001-2010. In addition, the frequency distribution of the terms by genre in COCA was also investigated.

In order to study the connotative meaning of these terms the online 'collocates or context-based search' in COCA was used to get a list of the most frequent nouns and adjectives that collocate with the terms. The strongest 20 collocates were only considered. Irrelevant words and repeated ones (plural forms) were removed from the search list. The most frequent adjective and noun collocates found within five words to the left and right of each term were examined.

Moreover, in examining the history of the meaning and the use of each term, a number of books on the history of English and some dictionaries of English etymology as well as other historical dictionaries like The Oxford English Dictionary (1961) that dates and documents all of the meanings of a word throughout the history of English were consulted.

\section{Results and Discussion}

\subsection{Frequency of Occurrence and Distributions}

Among the twenty surveyed terms that gained wide frequency after the September $11^{\text {th }}$ attacks, the following were identified as the most frequent terms used in COCA:

Table 1. Frequency of occurrence in COCA by years

\begin{tabular}{llllll}
\hline No & Arabic Loanwords & \multicolumn{2}{l}{$\begin{array}{l}\text { Before 9/11 } \\
1990-2000\end{array}$} & \multicolumn{2}{c}{ After 9/11 } \\
\cline { 3 - 6 } & & NF & $\%$ & NF & $\%$ \\
\hline 1. & Sunni(s) & 380 & $\mathbf{9}$ & 3.917 & $\mathbf{9 1}$ \\
2. & Jihad (s) & 363 & $\mathbf{1 7}$ & 1.819 & $\mathbf{8 3}$ \\
3. & Islamist(s) & 254 & $\mathbf{3 0}$ & 587 & $\mathbf{7 0}$ \\
4. & Fatwa & 63 & $\mathbf{2 3}$ & 207 & $\mathbf{7 7}$ \\
\hline
\end{tabular}


Table 2. Frequency of occurrence in COCA by years

\begin{tabular}{|c|c|c|c|c|c|}
\hline \multirow[t]{3}{*}{ No } & \multirow[t]{3}{*}{ English Terms } & \multirow{2}{*}{\multicolumn{2}{|c|}{$\begin{array}{l}\text { Before 9/11 } \\
1990-2000\end{array}$}} & \multirow{2}{*}{\multicolumn{2}{|c|}{$\begin{array}{l}\text { After } 9 / 11 \\
2001-2011\end{array}$}} \\
\hline & & & & & \\
\hline & & $\mathrm{NF}$ & $\%$ & $\mathrm{NF}$ & $\%$ \\
\hline \multirow[t]{2}{*}{1.} & Terrorist & 4.881 & 19 & 20,626 & 81 \\
\hline & Terrorism & 3.231 & 21 & 12.012 & 79 \\
\hline \multirow[t]{2}{*}{2.} & Radical & 8.027 & 51 & 7.739 & 49 \\
\hline & Radicalism & 443 & 66 & 225 & 34 \\
\hline 3. & Militant(s) & 1.962 & 32 & 4.248 & 68 \\
\hline \multirow[t]{2}{*}{4.} & Fundamentalist & 1.859 & 51 & 1.769 & 49 \\
\hline & Fundamentalism & 617 & $\mathbf{5 0}$ & 625 & 50 \\
\hline
\end{tabular}

One main thing that can be first noted about these terms is that some of them are primarily related to Islam and its language, the Arabic language, and the other ones, however, are of English origin but they have been frequently applied in relation with Arabic and Islamic groups in the political discourse of the 'War on Terror'. Some of these English terms like 'radicalism' originated within a religious Christian context and then were transferred from that religious sphere to a political one.

As it can be noted from the Tables 1 and 2, there is a remarkable increase in the percentage / number of frequency (NF) of most terms after the September $11^{\text {th }}$ attacks when compared with that percentage / number in the time prior to the attacks, more specifically between the years 1990-2000. The reason for this is unquestionable. The September $11^{\text {th }}$ attacks came to dominate public attention and the political scene recently. Western journalism began describing, presenting and debating the incidents. This in turn has led such terms used in relation with the attacks to come into widespread use. Given this, two conclusions can be abstracted at this level. First, native speakers of English and especially the Americans are far more aware of these terms than they were before. Second, journalists, news commentators, politicians and academics started using the terms far more than they did years before this time. However, it is worth noting at this point that the two terms 'fundamentalist/fundamentalism' and 'radical' have kept somewhat the same level of frequency before and after the attacks. This can be attributed to the fact that these terms gained strong prominence in the first place with the rise of the Iranian Revolution (1979) (Kramer, 2003 cited in Rababah, 2008, p. 91) as they were applied by Western journalists in describing the ideology of that revolution. The resurgence of some terms like 'Islamic fundamentalism' and 'radical Islam' in the wake of the Iranian Revolution and in other periods of time before the September $11^{\text {th }}$ attacks can explain the maintenance of the same level of frequency of these terms in the two time periods. For instance, Western journalism before September $11^{\text {th }}$ continually employed the term 'radical' when referring to some religious groups and movements like the Shi'it movement Hisbullah, the Abu Sayaf group in the Philippines and the Algerian Armed Islamic Group (Rababah, 2014). It seems that the wide currency of these terms have continued to happen even after the attacks as they were applied in describing the Taliban movement and the Al-Qaeda organization.

Another thing that can be noted from the same tables is that the Arabic loans increased a bit more sharply in percentage of frequency after the attacks when compared with that of the English ones. For instance, the percentage of frequency of 'Sunni' which is the top first term in the frequency list of Arabic terms has arisen from $9 \%$ to $91 \%$ before and after the attacks, respectively. However, the percentage of frequency of its English counterpart, 'terrorist' has arisen from $19 \%$ to $81 \%$. Other parallel differences can be found when making a similar comparison between the two groups of terms in both tables over the two indicated time periods. This reflects a growing attention to such terms related to the language and culture of those religious movements and organizations involved in the attacks and other related events like Taliban and Al-Qaeda. Moreover, a closer examination of the nature of these terms indicates that unlike those early loans referred to previously that came into English during the Two World Wars and were of a military nature, (e.g., flack, blitzkriegs) these all belong to the politics and the culture of the Arabic and Islamic region (e.g., jihad, Sunni). This might be due to the fact that the nature of the conflict in both situations is different. A cultural and ideological clash is involved in the second one, a fact that has raised more interest in the Islamic and Arabic cultures, thereby giving wide circulation to new related Arabic and Islamic terms. 
Table 3. Frequency distribution of the terms in COCA by genre

\begin{tabular}{|c|c|c|c|c|c|c|c|c|c|c|c|c|}
\hline \multirow[t]{3}{*}{ No } & \multirow[t]{3}{*}{ Term } & \multicolumn{11}{|c|}{ Genre Category } \\
\hline & & \multirow{2}{*}{$\begin{array}{l}\text { All } \\
\mathrm{NF}\end{array}$} & \multicolumn{2}{|l|}{ Spoken } & \multicolumn{2}{|c|}{ Fiction } & \multicolumn{2}{|c|}{ Magazine } & \multicolumn{2}{|c|}{ Newspapers } & \multicolumn{2}{|c|}{ Academic } \\
\hline & & & $\mathrm{NF}$ & $\%$ & $\mathrm{NF}$ & $\%$ & $\mathrm{NF}$ & $\%$ & $\mathrm{NF}$ & $\%$ & $\mathrm{NF}$ & $\%$ \\
\hline 1. & Sunni(s) & 4.658 & 1.529 & 33 & 17 & 0.36 & 588 & 13 & 1.567 & 34 & 957 & 20 \\
\hline 2. & Jihad (s) & 2.480 & 632 & 26 & 94 & 3 & 348 & 14 & 686 & 28 & 720 & 29 \\
\hline 3. & Islamist(s) & 3.486 & 349 & 10 & 7 & 0.2 & 343 & 10 & 710 & 20 & 2.077 & 60 \\
\hline 4. & Fatwa & 296 & 31 & 10 & 17 & 6 & 79 & 27 & 75 & 25 & 94 & 32 \\
\hline \multirow[t]{2}{*}{5.} & Terrorist & 25.507 & 10.532 & 41 & 1255 & 5 & 3.722 & 15 & 5.945 & 23 & 4.053 & 16 \\
\hline & Terrorism & 15.243 & 6.370 & 41 & 206 & 1 & 1.904 & 13 & 3.291 & 22 & 3.472 & 23 \\
\hline \multirow[t]{2}{*}{6.} & Radical & 15.766 & 2.545 & 16 & 625 & 4 & 3.883 & 25 & 2.735 & 17 & 5.978 & 38 \\
\hline & Radicalism & 668 & 62 & 9 & 7 & 1 & 124 & 18 & 77 & 12 & 398 & 60 \\
\hline 7. & Militant(s) & 6.210 & 1.563 & 25 & 132 & 2 & 719 & 11 & 2.543 & 42 & 1.253 & 20 \\
\hline \multirow[t]{2}{*}{8.} & Fundamentalist & 3628 & 605 & 17 & 97 & 3 & 962 & 27 & 738 & 20 & 1.226 & 33 \\
\hline & Fundamentalism & 1242 & 168 & 14 & 14 & 1 & 299 & 24 & 176 & 14 & 585 & 47 \\
\hline
\end{tabular}

Table 3 shows the frequency distribution of the terms in COCA by genre. A glance at this table shows that all of the terms exist in the different types of text sources in the corpus with varying levels of frequency of occurrence. These include spoken texts, fiction, popular magazines, newspapers and academic journals. The occurrence of the terms in all of these texts, though to varying degrees, highlights the wide spread and diffusion of such terms. In fact, when an important historical and political event like the September $11^{\text {th }}$ attacks takes place, it gives rise to new ideas and new experiences that in turn lead to a wide circulation of new terms and phrases used in connection with it and after a period of time, such terms and phrases begin hovering in every kind of news sources and different types of texts including even fiction. Expectedly, the military and politicians play an important role in coining and circulating these new words and phrases. For example, many of the words and phrases that arose in the wake of September $11^{\text {th }}$ were coined and popularized by President George Bush (e.g., The War on Terror) and other Pentagon spokespeople. This is revealed in the wide popularity that the terms 'terrorism' and 'terrorist' have gained in the years following the attacks as they were continually and since the first day of the attacks used by George Bush and politicians in describing the attacks and those members of Al-Qaeda who launched and orchestrated them.

Expectedly, all of the terms have the least number of frequencies in fiction. In fact, such politically and religiously oriented terms would not occur with a high level of frequency in works of fiction as in other non-fiction genres that deal mainly with factual political events taking place in the real world. However, their existence in fiction, though with a low degree can indicate as mentioned before the wide spread and the growing attention that they have gained after the attacks. It seems that the spread of these terms was so strong that they find their own way even in fiction.

A look at the number of the frequency of occurrence of the terms in other non-fiction genres shows that like in fiction most of the terms have a somewhat lower percentage of frequency in popular magazines when compared with spoken texts, newspapers and academic journals. However, this is not the case with the terms 'fatwa', 'radical/ radicalism' and 'fundamentalist/fundamentalism' that have a lower percentage of frequency in spoken texts rather than in magazines. The percentage of frequency of these terms in magazines is $25 \%$ for 'fatwa', $25 \%$ / $18 \%$ for 'radical/radicalism' and $27 \% / 24 \%$ for 'fundamentalist/ fundamentalism'; however, their percentage of frequency in spoken texts is $10 \%, 16 \% / 9 \%$ and $17 \% / 14 \%$, respectively. In contrast to this, when considering the frequency of occurrence of other terms in spoken texts, it can be noted that of all of the investigated terms the top first ones (in both groups of terms) 'Sunni' and 'terrorist/terrorism' have the highest percentage in spoken texts accounting for $33 \%$ and $41 \%$ / $41 \%$ respectively. Given the fact that the source of spoken texts in COCA is unscripted conversation from radio and TV shows (Davies \& Gardner, 2013, p. 3) and these might have been mostly overtaken by the rhetoric of the 'War on Terror', it is not unexpected to notice this high level of frequency of the terms in spoken text. This might be the case because these two terms seem to have the strongest connection with the attacks. Such a strong connection is the consequence of the repeated use of these two terms when identifying and describing those governments, organizations and movements (e.g., Al-Qaida, Taliban, Saddam Hussein's past government in Iraq) in the narrative that dominated the 'War on Terror' discourse. Such organizations and movements have been regularly referred to as 'Sunni terrorist'. In addition, since some of the popular magazines in this corpus deal with other social issues (women, health and economics) (ibid) unrelated to news and politics, such political terms will receive little attention and so lower the degree of frequency in them. 
Most of the terms, however, have somewhat a higher level of frequency of occurrence in newspapers and academic journals. In fact, newspapers are one of the main news sources that represented the attacks and other subsequent related events, and this in turn led those terms used in connection with the attacks to gain wider currency in them. Similarly, it seems that the academics have been paying more attention to most of these terms in their writings. However, it is important to note that among all of the items the terms 'Islamist', 'radical/ radicalism' and 'fundamentalist/fundamentalism' have the highest number of frequency in academic journals accounting for $60 \%, 38 \% / 60 \%$ and $33 \% / 47 \%$, respectively. Perhaps, when describing the ideology and origins of those religious groups and movements involved in the attacks, these terms were the most frequently used terms in academic circles.

\subsection{Origins, History of Meaning and Use of the Terms}

Before going further to study the connotative meaning of the terms, a brief historical background is given in which the gradual sense development of each term is traced along history. Initial intuitions and hypothesis based on the background regarding the connotative meaning of these terms are examined and tested by analyzing the strongest collocates of each term in COCA.

\subsubsection{Sunni}

The term 'Sunni' is an old loanword in English that has been revived and gained wide circulation after the September 11th attacks. The Online Etymology Dictionary dates the term back to the early 17th century and defines it as the 'Muslims who accept the orthodox tradition as well as the Quran'. However, one can argue that this term has developed negative connotations in recent years following the attacks. This might have resulted as indicated earlier from its regular use in relation with the attacks and their preparators. However, it seems that, in addition to this, the recurrence of the term in the context of the War on Iraq (2003) has further contributed to this change of meaning as it was used in connection with the sectarian conflict existing between Sunnis and Shiites in Iraq. It seems that the use of 'Sunni' in such a negative context of sectarian violence has loaned it with further negative connotations. Moreover, the resurgence of the phrase 'Sunni Triangle' in the wake of the War on Iraq (2003) has further strengthened this change of meaning. The 'Sunni Triangle' is an area of Sunni communities in Baghdad, the most loyal to Saddam Hussein, which includes the cities of Fallujah, Ramadi and Tikrit. During the war, it was the place where the American troops faced the greatest resistance as most explosions, car bombings and kidnappings took place in it (Monteverde, 2005, pp. 11-12). Perhaps the use of the term 'Sunni' in such a context that is characterized by violence and atrocity had colored it with a negative connotation. In fact, such a negative connotation that the term 'Sunni' has come to have can be confirmed by the questionnaire results in the study conducted by Taha (2006), in which it is revealed that most of the respondents of the questionnaire had perceived the term 'Sunni (s)' negatively accounting for (51.9\%) (see literature review).

To testify the claims made before regarding the negative connotation that this term has come to have, it is important to consider the type of words that tend to collocate with it in COCA. Tables 4 and 5 (see Appendix B) display the twenty strongest both adjective and noun collocates of the term 'Sunni' in this corpus.

One main first thing that can be noted in these two tables is that the two words 'Shiite' and 'Shiites' are the strongest collocates of 'Sunni. This in fact proves the co-occurrence of the term in that negative context of the tension existing between the two Islamic sects; 'Sunni' and 'Shiite'. This can also be further supported by other collocates with negative prosodies such as 'attacks', 'violence' and 'war' in Table 5 and 'sectarian' in Table 4. Similarly, the word 'triangle' also collocates strongly with the term having a high number of frequencies (156). This also indicates the adoption of the term in another negative context, referred to previously as related to the 'Sunni Triangle' region in Iraq.

There are other collocates of the term with lower frequencies in both tables that seem, however, to have neutral semantic prosodies. These are words indicating demographic and ethnographic distributions such as 'country', 'population' and 'groups' in table 5 and 'other' in table 4. However, this might imply embedded negative attitudes in the collocation pattern that create a sense of separation between the 'self' and the 'other' in the world of "Sunni" countries, population or groups. This may also indicate the negative connotation of the term which is displayed in this lexical selection. This can be based on Stubbs' argument that semantic prosody is a matter of lexical selection (see p. 3).

Other emotive or loaded words that have negative semantic prosodies tend also to collocate, though with lower frequencies, with 'Sunni'. These are 'insurgency, 'insurgents' and 'extremist' in Table 5 and 'radical' in Table 4.

In short, most of the collocates of the term 'Sunni' indicate the negative connotation that it has come to have due to its co-occurrence with such words associated with violence and tension. 


\subsubsection{Jihad}

Like the term 'Sunni', 'jihad' is not a new borrowing in English. However, this term has been resurrected and given new connotations after the September $11^{\text {th }}$ attacks. 'Jihad' is an old term that entered English in 1869 with the meaning of 'holy war'. By 1880, it also meant 'any doctrinal struggle' (the Oxford English Dictionary, 1961). The literal meaning of 'jihad' in Arabic is 'holy struggle' or 'striving'; however, this meaning of 'strive' or 'struggle' is rarely known in English and the only meaning associated with it is 'holy war' as Western news media following the September $11^{\text {th }}$ attacks used the word with only this restricted sense (Knapp, 2003, p. 82 cited in Rababah, 2008, p. 77). In fact, 'jihad' has many meanings and one of those is 'holy war'. In Arabic, 'jihad' indicates 'exerting efforts' to achieve a particular goal (Fatoohi, 2004 cited in Rababah, 2008, p. 77). Given this, it can be claimed that the term after the attacks had a pejoration in its meaning being that it is only used with one restricted sense which is 'war'. It seems that this meaning has come to be associated with negative connotations of 'terror' and 'threat' as it has been continually used in the context of the 'War on Terror' in connection with the attacks and terrorist suspects. After September $11^{\text {th }}$, Al-Qaeda called its attacks against the U.S a 'jihad'. This led the term to be perceived negatively being strongly associated with terrorism.

A note on the strongest collocates of 'jihad' displayed in Tables 6 and 7 can in fact imply this change in its meaning. A close examination of the type of these collocates can reveal both the pejoration and the restriction that the meaning of 'jihad' came to have.

From these two tables, it can be noticed that the two words 'holy' and 'war' come at the top of both lists revealing their strong co-occurrence with 'jihad'. This in fact supports what has been indicted earlier about the restriction in the denotative meaning that this term has undergone as it is continually used with one single meaning which is 'holy war'.

Other collocates in both tables seem to reflect the negative connotation of the term. Many emotive or loaded words like 'militants', 'radical', 'struggle', 'violent' and 'terrorists' co-occur with the term with various degrees of frequency of occurrence. Of these words the word 'violent' has the highest degree of frequency (75). It seems that such a co-occurrence of these words with 'jihad' has loaned it with strong negative prosodies or connotations. However, it is important to note that the term also collocates with other proper names like 'Laden', country and nationality names like 'Afghan', and 'Palestinian' and names of political and religious movement like Hamas'. Although these words do not seem to carry very strong negative connotations like those emotive ones mentioned before, they can still indicate the negative context in which the term 'jihad' is usually adopted. For instance, the words 'Laden' and 'Afghan' are usually used in context of the 'War on Terror' discourse. The same thing applies to Hamas which was classified by the U.S as a terrorist movement. Other collocates of military and political nature can also indicate negative prosodies embedded in the collocation pattern of the term. These are 'leader', 'front', 'organizations', 'political' and 'movements'. This further indicates a political slant given to such a religious term like 'jihad'.

\subsubsection{Islamist}

The term 'Islamist' entered the English language in the $19^{\text {th }}$ century simply meaning having to do with Islam; however, it developed a different meaning in time referring to someone who professes the tenets of Islam but embraces extreme ideas (Park, 2006). A close study of the history of the term can indicate this change of meaning; The Oxford English Dictionary dates 'Islamist' to the mid $19^{\text {th }}$ and $20^{\text {th }}$ centuries with the meaning 'orthodox Muslim' or 'one who is versed in Islamic studies', respectively. However, The Oxford Advanced Learners' Dictionary of Current English (seventh edition) offered a more contemporary sense of 'Islamist' defining it as 'a person who believes strongly in the teachings of Islam'. It seems that the term developed a pejorative connotative meaning after the September $11^{\text {th }}$ attacks that has to do with extremism and terrorism due to its repeated use in connection with some religious Arabic groups that are considered terrorist groups. Fuller (2003) criticized this application of the term saying:

While ignoring the overwhelming majority of Islamists who have nothing to do with terror and making them virtually irrelevant and stigmatized in Western political discourse ... To ignore the complexity of political Islam and tar all Islamists with the same brush of terrorism guarantees Bin Laden's success (Fuller, 2003, p. 83).

An examination of those collocates of 'Islamist' displayed in Tables 8 and 9 reveals the negative sense of extremism and terrorism that the term has come to have. As the case with the terms 'Sunni' and 'jihad', 'Islamists' tend to collocate strongly with emotive words with strong negative prosody. This is displayed by the collocates 'radical', 'militant', 'terrorist', 'violent' and 'extremist' in Table 8 and 'terror', 'regime' and 'war' in Table 9. The negative connotative meaning that the term has acquired due to its application to some religious 
Arabic political groups is evident in its co-occurrence with some words like 'Arab' and 'Palestinians' in Table 8 and 'groups', 'movement' and 'party' in Table 9 . The fact that most of these words come at the top of the list indicates a high level of frequency that shows the strong connection between these words and the term 'Islamist'.

\subsubsection{Fatwa}

Like 'Sunni', 'jihad' and 'Islamist', the term 'fatwa' has developed new connotations after the attacks. The term 'fatwa' is an old Arabic word which was loaned into English in the 17th century (The Online Etymology Dictionary dates the term back to 1620s). Perhaps the term 'fatwa' was first popularized in English in the late 1980s when the political leader of Iran, Ayatollah Khomeini in 1989 issued a fatwa to kill Salman Rushdie for his novel The Satanic Verses (1988) which he considered blasphemous for its depiction of the life of the prophet Mohammad (Thackrah, 2013, p.98). Following the terrorist attacks, the term 'fatwa' gained new prominence as many English newspapers and journals (e.g., Boston Globe, Los Angeles Times) started quoting the full text of a document written by Bin Laden in 1998 in which he issued a fatwa to kill the Americans in response for any U.S attack on Iraq. It seems that the use of 'fatwa' in such negative contexts has led the word to develop pejorative connotations beyond its conceptual meaning. According to Merriam Webster's Dictionary, 'fatwa' means "a legal opinion or decree handed down by an Islamic religious leader". In fact, this religious ruling can be decreed on anything in life. However, it seems that after the attacks, the word has had a restriction in its meaning as it was generally used to mean a religious ruling for killing. In this way, the word has come to carry negative connotations of death, threats and murder.

Interestingly, this change of meaning is confirmed by the collocates of the term 'fatwa' in COCAE. Tables 11 and 12 introduce the strongest collocates of this term.

It is notable that the collocation patterns in both tables are so similar. The hypothesis made before regarding the negative meaning of death and threat that 'fatwa' has developed recently is evident from its co-occurrence with some emotive words with strong negative prosodies like the words 'blasphemous' and 'terrorist' in Table 10 and 'death', 'violence' and 'terrorism' in Table 11. However, although other nouns that appear at the top of the list of the noun collocates like 'Ayatollah', 'Khomeini', 'Rushdie', 'Iran' and 'Laden' seem to carry less negative connotations, they still indicate the negative context related to the fatwa issued against Rushdie by Khomeini and the fatwa issued against the U.S by Ben Laden. In short, all of these collocates tend to support the hypothesis about the negative connotation and the restriction of meaning of the word 'fatwa'.

\subsubsection{Terrorist/ Terrorism}

Like the case with other Arabic loanwords, a study of the history of the meaning and the use of the term 'terrorism' can show that it has passed through many stages of semantic change. In tracing the sense development of this term, it can be noticed how this term was associated with western state and non-state actors and it has become nowadays highly linked with Middle Eastern Arab and Muslim groups.

Halliday (2004) showed systematically how the term 'terrorism' was solely associated with the Westerner political sphere. He stated that 'terrorism' evolved as an act of state against its people when the French government pursued all aggressive means against French revolutionists on the eve of the French Revolution (1789-1795). A similar situation can be applied in Russia during the early years of the 20th century when the 'Bolshevik' leader, Trotsky wrote his book, In Defense of Terrorism (1921), defending the actions or the rights of revolutionists to attain independence and freedom (ibid). Hence, the origin of the term reveals its connection with acts of violence carried out by states or governments. This is confirmed by the Oxford English Dictionary (1961) which dates the term 'terrorism' back to the end of the 18th century and the end of the 19th century applying it respectively to 'Jacobins in the French revolution' and 'members of one of the extreme revolutionary societies in Russia'.

However, since the end of the Second World War, many occupied states sought independence through guerilla wars against their governments who were affiliated or appointed by colonial powers, so the occupying armies called attacks by resistance fighters terrorism (Skoll, 2007, p. 108). The term terrorism then took a semantic shift as it was used in reference to non-state actors, such as the Irish Republican Army (Halliday, 2004). In light of this, it can be stated that there was a gradual shift in the meaning of terrorism from state to non-state actors.

Considering this stage of change in the meaning of 'terrorism', it seems that to some extent the meanings of words are determined by political powers that are able to manipulate words in their favor. As mentioned before, in its first use, the term was applied to describe acts of violence conducted by governments or states against non-state groups. Since governments and political powers started applying the term in reference to non-state fighters and groups, the term shifted in meaning. The restricted use of the term by political powers that control 
media may have caused the term to shift in meaning. Hence, when individuals, groups or organizations use violence they are called terrorists, but states are not. As Skoll (2007) indicated:

Most commentators take a statist viewpoint according to which individuals, groups, or organizations using violence are terrorists, but states are not. A few academic studies have recognized state terrorism, and the very exceptional point out that state terrorism is and has been the most prevalent and consistent kind of terrorism over the centuries (Skoll, 2007, p. 109).

The other stage of semantic change took place by the end of the $20^{\text {th }}$ century as 'terrorism' became associated with Arab Middle Eastern revolutionary groups. During that period, the intensity of the Palestinian issue entitled some Palestinian groups to conduct a variety of new confrontational activities such as hijacking airplanes and kidnapping foreign politicians (Halliday, 2004). The term became more attached to Arabs and even Muslims in recent years especially after the September $11^{\text {th }}$ attacks. It can be argued that 'terrorism' has not taken a new shift since these events, but rather it has acquired a broader associative sense to include Muslims along with Arabs. While the term used to refer to the use of violence by any group regardless of its religion, ethnicity or its culture, it has now become strongly associated with Arabs and Muslims. It can be argued that in the political context related to the September $11^{\text {th }}$ attacks and the 'War on Terror', the term 'terrorism' has developed a particular collocative meaning that conjures associations with Arabs and Muslims.

In studying the strongest collocates of 'terrorism' in COCAE, it can be noted that the word 'Islamic' appears among the top first adjective collocates having a higher number of frequency accounting at 134 and 277 in Tables 12 and 13, respectively. This proves the idea that the term 'terrorist/terrorism' has developed a negative meaning that has to do with Islam.

\subsubsection{Radical / Radicalism}

Like the term terrorism, the term 'radical' has passed through different stages of semantic change through history. According to Wood (1961) the term 'radical' entered English in the $17^{\text {th }}$ century with the meaning 'thorough'. Then, it gained a pejorative sense as it was used to refer to the Orthodox teaching of the Church. People were dissatisfied with the rigidity and conservatism of the Orthodox teachings and the Orthodox interpretation of the scripture 'who wanted to probe the bottom of things and search out the truth for themselves' (180-181). In the $19^{\text {th }}$ century, the term extended its meaning as it came to refer to people holding extreme views whether religious or political ones (ibid). This extension of meaning is confirmed by the definition of the term given in Merriam Webster Online Dictionary that defines it as 'having extreme political or social views that are not shared by most people'. In later years, one can argue that the term 'radical' gained a connotative collocative meaning that has to do with 'terrorism' and 'Islam'. As Sirozi (2004) indicated since the Cold War and the rise of 'international terrorism', 'radical' has been used to describe terrorists and since many suspects are Muslims the term came to be associated with Islam (166).

Such an association appears clearly in Tables 14 - 17. As it can be noted in these tables the word 'Islam' and its derivative forms come at the top of the list of the collocates of 'radical/ radicalism'. For instance, the word 'Islamic' comes first in the list of collocates in Table 16. Similarly, the word Islam appears third in Table 15. In addition, the term 'radical/radicalism' co-occur with negative emotive words like 'extreme' in Table 16, 'conservatism', 'extremism', 'terrorism', 'threat' and 'fundamentalism' in Table 17.

\subsubsection{Militant}

Like the term 'radical', the term 'militant' acquired different meanings through history. The Online Etymology Dictionary dates the term back to the $15^{\text {th }}$ century that was loaned into English from French as an adjective with the meaning 'fighting, engaged in warfare'. In its general sense, 'militant' means 'aggressive' and 'warlike'. However, the term extended in meaning to mean fighting for an idea or a cause as it was applied to a political activist. Thus, 'militants' as a noun is used to refer to those who dedicate themselves to a party that takes a strong position for any cause. However, the term has been loaded with a pejorative connotative meaning usually suggesting someone who is irrationally dedicated to a cause that is not acceptable to the speaker and associated with violence as it is often used synonymously with 'radical' or interchangeably with 'fanatic' and the attack word 'agitator'(Herbst, 2003, p. 115). It seems that this term pejorated in meaning due to its use in connection with black people in the 1960 s with the rise of the civil rights movement as media made many references to 'black militants' (ibid). Hence, the term is usually associated with 'terrorism' and 'extremism'. In citing examples on the use of the term, Herbst (2003) referred to the 1976 movie The Enforcer in which a police inspector chases a "group of black militants with enough explosives to blow out half of San Fransisco" (115). 
However, the term 'militant' has recently come to be associated with Islamic groups as Said (1997) criticized the way the militant references directed against militant activists suggesting the irrationality of their acts and so illegitimating their cause in the eyes of others (ibid). After the September $11^{\text {th }}$ attacks, this link between 'militant' and 'Islam' has grown sharply as the western media started describing members of Islamic organizations like Al-Qaeda as 'militants'.

The strong association between the term 'militant' and 'Islam' is revealed in the high number of co-occurrence of the term with the word 'Islam' and its derivative form. For instance, the words 'Islamic' is the top position in the list of collocates in Table 18 and the same thing applies to 'Islam' that comes in the second position in Table 19. Other words referring to Islamic religious groups also collocate strongly with 'militant'. These are 'Taliban' and 'Al-Qaida' in Table 18 and 'Hamas' in Table 19.

\subsubsection{Fundamentalist/ Fundamentalism}

The term 'fundamentalism' has also followed the same process of semantic change that the term 'terrorism' has had in developing an associative collocative meaning that has to do with Islam. The term 'fundamentalism' was first applied to a conservative Protestant movement that attempted to impose its religious beliefs. The term originated in the1920s in America when Protestant Christians found themselves under the threat of the increased criticism of the Bible and the spread of philosophical skepticism. These Christians called themselves 'fundamentalists' as "they sought to reaffirm their belief in the literal text of the Bible and the fundamentals of Christian belief" (Lewis, 1988, p. 117).

In the following decades, the term had an extension in its meaning, as it was widely used in reference to some Islamic groups and regimes and always suggested negative connotations. This semantic extension took root with the rise of the Iranian Revolution of 1979-80. In their attempts to explain the ideology of Ayatollah Khomeini and the Revolution, journalists started describing it as a "fundamentalist version of Islam" by way of analogy to the Christian fundamentalist movement in America. This gave birth to the term 'Islamic fundamentalism' which came into widespread use in the media coverage of the revolution (Kramer, 2003, p. 67). The use of 'fundamentalism' in connection with Islam spread so widely that the term began to extend and generalize in its semantic scope to mean strong adherence to the beliefs of any religion. For instance, by 1990, the Concise Oxford English Dictionary defined it not only as "the strict maintenance of traditional Protestant beliefs", but also as "the strict maintenance of ancient or fundamental doctrines of any religion, especially Islam" (ibid). Similar definitions can be found in other dictionaries like Merriam Webster's Dictionary and TheAmerican Heritage Dictionary.

In later years following the revolution, many newspapers started using 'fundamentalism' synonymously with 'extremism' and 'terrorism' to describe any religious group that causes troubles or uses violence for political reasons. In fact, this misuse of such a religious term by journalists has loaded it with strong emotional overtones or connotations that evoke strongly negative reactions beyond its literal or conceptual meaning. As Jackson (2002) indicated, 'fundamentalist' and 'fundamentalism' came to spread particular negative connotations or what he called negative "semantic prosodies" in the context in which they occur (16). Taking the term in its literal sense, "the adherence of the basics of one's religion" does not imply violence. Being a fundamentalist does not mean being a terrorist. All followers who adhere to the basic teachings of any particular religion whether it be Christianity, Judaism or Hinduism are also "fundamentalists". All Muslims who follow the basic teachings of Islam are called "fundamentalists" (Ahmed, 1993, pp. 18-19, cited in Rababah, 2008, p. 92). However, a negative connotation is attached to the term and always linked with Islam. Said (1997), a critic of Western representations of Islam, criticized the adoption of 'fundamentalism' against Islam:

Instead of scholarship, we often find only journalists making extravagant statements, which are instantly picked up and further dramatized by the media. Looming over their work is the slippery concept, to which they constantly allude, of "fundamentalism", a word that has come to be associated almost automatically with Islam, although it has a flourishing, usually elided relationship with Christianity, Judaism, and Hinduism. The deliberately created associations between Islam and fundamentalism ensure that the average reader comes to see Islam and fundamentalism as essentially the same thing (Said, 1997, p. xvi, cited in Kramer, 2003, p. 67).

In the last years immediately following the September 11th attacks, the link between Islam and fundamentalism has grown sharply as the issue of "Islamic fundamentalism" became a central concern in American and western media. This strong association of the term 'fundamentalism' is revealed in the Tables 20-23.

In these tables the words 'Islamic' and 'Islam' tend to occur with 'fundamentalism' with higher degrees of frequencies when compared with the word 'Christianity' / 'Christian' and other words related to it such as 
'Biblical' and 'Protestant'. This proves the idea that the term 'fundamentalism' has developed a stronger association with Islam than with Christianity. The negative connotation of the term is apparent from its co-occurrence with emotive words such as 'radical', terrorism', 'fanaticism', 'extremism' and 'militant'.

\section{Conclusion}

The study has examined the connotative meaning of some politically and religiously oriented terms that gained wide circulation in the wake of the September $11^{\text {th }}$ attacks. An examination of the sense development of these terms through history has shown that most of them have undergone a restriction in their meanings being only used with one negative sense (e.g., jihad). This change of connotation has also been found evident in the type of their collocation patterns in the Corpus of American English. An analysis of the strongest collocates of these terms in the corpus has revealed that most of these terms tend to co-occur with negative emotive loaded words. In addition, an analysis of the meaning of the terms 'terrorist/terrorism', 'radical/radicalism', 'militant' and 'fundamentalist/fundamentalism' has shown that these terms have acquired a collocative meaning that has to do with Islam. Moreover, the study has found that the negative connotations or perceptions associated with these terms are affected by the conditions or the circumstances under which they initially evolved. Being widely used in connection with the attacks and as a main part of the 'War on Terror' discourse, the terms have come to be perceived with a high level of negativity and hence gaining pejorative meanings.

\section{References}

Baker, P. (2006). Using Corpora in Discourse Analysis. London: Continuum.

Baugh, C., \& Cable, T. (1993). A History of the English Language. New Jersey: Prentice-Hall.

Beard, A. (2004). Language change. London: Routledge.

Chimombo, M., \& Roseberry, R. L .(1998). The Power of Discourse: An Introduction to Discourse Analysis. Mahwah, NJ: Lawrence Erlbaum Associates

Davies, M. (2008). The Corpus of Contemporary American English: 450 million words, 1990-present. Retrieved from $\mathrm{http} / / / \mathrm{www}$. wordfrequency.info/free.asp?s=y.

Davies, M., \& Gardner, D. (2013). Frequency Dictionary of American English. New York: Routledge.

Durie, M., \& Ross, M. (1996). The Comparative Method Reviewed: Regularity and Irregularity in Language Change. New York: Oxford University Press.

Estrich, R., \& Sperber, H. (1952). Change of Meaning. In Kottler, B., \& Light, M. (Eds.), (1967). The world of Words (pp.107-118). Boston: Houghton Muffin Company.

Fuller, G, E. (2003). The Future of Political Islam. New York: Palgrave Macmillan.

Halbe, D. (2013). English in Business Meetings: A Corpus Study of Directives and Lexis in National and International Settings. Berlin: Epubli.

Halliday, F. (2004). Terrorism in Historical Perspective. OpenDemocracy.net. Retrieved May 7, 2007, from http://www.opendemocracy.net/globalization-madridprevention/article_1865.jsp

Heller, L. G., Humez, A. and Dror, M. (1984), The Private Lives of English Words. Indiana: Verbatim Books.

Herbst, P. (2003). Talking Terrorism: A Dictionary of the Loaded Language of Political Violence. New York: Greenwood Publishing Group.

Jackson, H. (2002). Lexicography: an Introduction. London: Routledge. http://dx.doi.org/10.4324/9780203467282.

Kramer, M. (2003). Coming to Terms: Fundamentalists or Islamists?. Middle East Quarterly, X, 65-77.

Leech, G. (1975). Semantics. London: Penguin U.K.

Leith, D. (1997). A Social History of English. London: Rutledge.

Lewis, B. (1988). The Political Language of Islam. Chicago: University of Chicago Press.

Merriam-Webster Online Dictionary. (2013). 'Fatwa'. Retrieved December 20, 2014, from http://www.merriam-webster.com/dictionary/fatwa

Merriam-Webster Online Dictionary. (2013). 'Radical'. Retrieved December 26, 2013, from http://www.merriam-webster.com/dictionary/radical 
Minkova, D., \& Stockwell, R. (2001). English Words: History and Structure. Cambridge: Cambridge University Press.

Monteverde, M. (2005). America's Presence in Iraq: Winning the Peace. New York: The Rosen Publishing Group.

Murray, A. H. (ed.). (1961). The Oxford English dictionary; A new English dictionary on historical principles founded mainly on the materials collected by the Philological Society/Supplement and bibliography (12th ed.). Oxford: Clarendon Press.

Online Etymology Dictionary. (2001). 'Fatwa'. Retrieved December 26, 2014, from http://www.etymonline.com/index.php?allowed_in_frame $=0 \&$ search $=$ fatwa\&searchmode $=$ none

Online Etymology Dictionary. (2001). 'Militant'. Retrieved December 26, 2013, from $\mathrm{http}: / / \mathrm{www} . e t y m o n l i n e . c o m /$ index.php? search=taliban\&searchmode=none

Online Etymology Dictionary. (2001). 'Sunni'. Retrieved December 26, 2013, from http://www.etymonline.com/index.php?search=taliban\&searchmode=none

Park, W. (2006). Sept.11 Creates New Lexicons. FOXNEWS.com. Retrieved December 25, 2013, from http://www.foxnews.com/story/0,2933,213240,00.html

Partington, A. (1998). Patterns and Meanings - Using Corpora for English Language Research and Teaching. Amsterdam/Philadelphia: John Benjamins. http://dx.doi.org/10.1075/scl.2.

Rababah, A. (2008). The Effect of Social and Political Factors on Semantic Change and Lexical Growth (Unpublished master's thesis). The University of Jordan, Amman, Jordan.

Rabab'ah, G. (2014). The University of Jordan, Department of Political Sciences. Personal Communication.

Ruthven, M. (2005). Fundamentalism: The Search for Meaning. Oxford: Oxford University Press.

Sirozi, M. (2004). Perspective on Radical Islamic Education in Contemporary Indonesia: Major Themes and Characteristics of Abu Bakar Ba'asyir's Teachings. In R. Geaves (Ed.), Islam and the West Post 9/11 (pp. 166-193). Burligton, USA: Ashgate Publishing, Ltd.

Skoll, G. R. (2007). Meanings of Terrorism. International Journal for the Semiotics of Law, (20), 107-127. http://dx.doi.org/10.1007/s11196-006-9038-5.

Stewart, Dominic. (2010). Semantic Prosody: A Critical Evaluation. New York: Routledge.

Taha, T. (2006). College Students' Evaluative Reactions to Arabic Loanwords Used in the Context of the Iraq War. Education, 127(1), 86-94.

Thackrah, J. R. (ed). (2013). Dictionary of Terrorism. London, UK: Routledge.

Wood, F. (1961). An Outline History of the English Language. New York: MacMillan Company.

Zhang, C. (2012). An Overview of Corpus-based Studies of Semantic Prosody. Asian Social Science, 6(6), 190-194.

\section{Notes}

Note 1. The phrase 'War on Terror' was first used and popularized by the U.S. President George W. Bush on 20 September 2001 in reference to military and political campaigns against organizations like al-Qaeda and regimes supporting them. Since that time Western media started adopting widely this new use of this phrase (Robinson, 2008, p. 88).

Note 2. The Corpus of Contemporary American English presents the number of frequency of a selected item in the years 1990-1994, 1995-1999, 2000-2004, 2005-2009 and 2010-2012. In order to study the number of frequency of the investigated terms in this study ten years before and after September 11, 2001, the number of frequency of each term in the year 2000 had been counted manually and added to the total number of frequency in the years 1990-1999. Similarly, the number of frequency of each term in the years 2011-2012 was also counted manually and extracted from the total number of frequency in the years 2001-2010. 


\section{Appendix A}

\section{Frequencies}

\begin{tabular}{lllll}
\hline & Arabic Loanwords & Frequency & English Terms/Phrases & Frequency \\
\hline 1. & Sunni(s) & 4.658 & Terrorism/ Terrorist & $15.243 / 25.507$ \\
2. & Jihad(s) & 2.480 & Radical(s)/ Radicalism & $15.766 / 668$ \\
3. & Islamist(s) & 3.486 & Militant(s) & 6.210 \\
4. & Fatwa(s) & 296 & Fundamentalist(s)/ Fundamentalism & $3.628 / 1.212$ \\
5. & Fedayeen & 196 & Detainee & 3.043 \\
6. & Madrassa (s) & 184 & Guantanamo & 2.254 \\
7. & Salafi & 105 & Neo-fascism & 979 \\
8. & Wahabi & 28 & Anarchist(s)/anarchism & $848 / 116$ \\
\hline
\end{tabular}

\section{Appendix B}

\section{Collocations}

Table 4. Adjective Collocates Within 5 Words to the Left and Right of 'Sunni'

\begin{tabular}{lll}
\hline No & Keyword & NF \\
\hline 1. & Shiite & 250 \\
2. & Muslim & 160 \\
3. & Iraqi & 128 \\
4. & Political & 94 \\
5. & Other & 78 \\
6. & Kurdish & 60 \\
7. & Religious & 46 \\
8. & Arab & 43 \\
9. & Sectarian & 41 \\
10. & Secular & 40 \\
11. & Islamic & 37 \\
12. & Tribal & 36 \\
13. & American & 28 \\
14. & Christian & 24 \\
15. & Major & 24 \\
16. & New & 24 \\
17. & Prime & 22 \\
18. & Military & 22 \\
19. & Kurd & 20 \\
20 & Radical & 20 \\
\hline
\end{tabular}

Table 5. Noun Collocates Within 5 Words to the Left and Right of 'Sunni'

\begin{tabular}{lll}
\hline No & Keyword & NF \\
\hline 1. & Shiites & 291 \\
2. & Arabs & 220 \\
3. & Muslims & 192 \\
4. & Insurgents & 179 \\
5. & Triangle & 156 \\
6. & Groups & 147 \\
7. & Minority & 131 \\
8. & Leaders & 123 \\
9. & Government & 114 \\
10. & Insurgency & 106 \\
11. & Majority & 89 \\
12. & Islam & 89 \\
13. & Areas & 80 \\
14. & Country & 67 \\
15. & Population & 62 \\
16. & Extremists & 69 \\
17. & Party & 59 \\
18. & Attacks & 44 \\
19. & Violence & 44 \\
20 & War & 40 \\
\hline
\end{tabular}


Table 6. Adjective Collocates Within 5 Words to the Left and Right of 'Jihad'

\begin{tabular}{lll}
\hline No & Keyword & NF \\
\hline 1. & Islamic & 646 \\
2. & Holy & 123 \\
3. & Palestinian & 80 \\
4. & Violent & 75 \\
5. & Egyptian & 50 \\
6. & Global & 46 \\
7. & American & 38 \\
8. & Other & 34 \\
9. & Afghan & 27 \\
10. & International & 27 \\
11. & Militant & 25 \\
12. & Muslim & 25 \\
13. & New & 25 \\
14. & Radical & 21 \\
15. & Terrorist & 21 \\
16. & Military & 20 \\
17. & Religious & 20 \\
18. & Laden & 18 \\
19. & Political & 16 \\
20 & Legitimate & 14 \\
\hline
\end{tabular}

Table 7. Nouns Collocates Within 5 Words to the Left and Right of 'Jihad'

\begin{tabular}{lll}
\hline No & Keyword & NF \\
\hline 1. & War & 132 \\
2. & Groups & 67 \\
3. & Jihad & 50 \\
4. & Hamas & 46 \\
5. & Muslims & 42 \\
6. & Movement & 40 \\
7. & World & 40 \\
8. & Islam & 38 \\
9. & Members & 32 \\
10. & Liberation & 31 \\
11. & Struggle & 30 \\
12. & Leader & 27 \\
13. & People & 26 \\
14. & Call & 22 \\
15. & Front & 22 \\
16. & Leaders & 22 \\
17. & Part & 21 \\
18. & Terrorists & 19 \\
19. & Organizations & 17 \\
20 & Militants & 16 \\
\hline
\end{tabular}

Table 8. Adjective Collocates Within 5 Words to the Left and Right of 'Islamist'

\begin{tabular}{lll}
\hline No & Keyword & NF \\
\hline 1. & Radical & 251 \\
2. & Other & 99 \\
3. & Political & 93 \\
4. & Militant & 78 \\
5. & Moderate & 59 \\
6. & Muslim & 57 \\
7. & Arab & 38 \\
8. & Secular & 36 \\
9. & Islamic & 35 \\
10. & New & 32 \\
11. & Terrorist & 31 \\
\hline
\end{tabular}




\begin{tabular}{lll}
\hline 12. & Palestinian & 27 \\
13. & Violent & 26 \\
14. & Growing & 22 \\
15. & Military & 22 \\
16. & Armed & 21 \\
17. & Social & 20 \\
18. & Western & 18 \\
19. & Egyptian & 18 \\
20 & Extremist & 18 \\
\hline
\end{tabular}

Table 9. Noun Collocates Within 5 Words to the Left and Right of 'Islamist'

\begin{tabular}{lll}
\hline No & Keyword & NF \\
\hline 1. & Groups & 203 \\
2. & Movement & 168 \\
3. & Party & 111 \\
4. & Movements & 96 \\
5. & Government & 87 \\
6. & Terrorism & 77 \\
7. & Militants & 61 \\
8. & Opposition & 59 \\
9. & Brotherhood & 53 \\
10. & Terrorist & 53 \\
11. & Regime & 49 \\
12. & State & 49 \\
13. & Power & 48 \\
14. & War & 48 \\
15. & Organizations & 44 \\
16. & Forces & 40 \\
17. & Threat & 35 \\
18. & Politics & 36 \\
19. & Extremism & 34 \\
20 & Terror & 28 \\
\hline
\end{tabular}

Table 10. Adjective Collocates Within 5 Words to the Left and Right of 'Fatwa'

\begin{tabular}{lll}
\hline No & Keyword & NF \\
\hline 1. & Religious & 50 \\
2. & Islamic & 14 \\
3. & European & 5 \\
4. & Laden & 5 \\
5. & Legal & 5 \\
6. & Muslim & 4 \\
7. & Issuing & 4 \\
8. & Other & 4 \\
9. & New & 3 \\
10. & Iranian & 3 \\
11. & Certain & 3 \\
12. & Blasphemous & 2 \\
13. & Egyptian & 2 \\
14. & American & 2 \\
15. & General & 2 \\
16. & Influential & 2 \\
17. & Infamous & 2 \\
18. & Irrelevant & 2 \\
19. & Grand & 2 \\
20 & Terrorist & 2 \\
\hline
\end{tabular}


Table 11. Noun Collocates Within 5 Words to the Left and Right of 'Fatwa'

\begin{tabular}{lll}
\hline No & Keyword & NF \\
\hline 1. & Edict & 19 \\
2. & Ayatollah & 17 \\
3. & Rushdie & 17 \\
4. & Ruling & 14 \\
5. & Khomeini & 13 \\
6. & Decree & 9 \\
7. & Death & 8 \\
8. & Attacks & 7 \\
9. & Sistani & 6 \\
10. & Iran & 5 \\
11. & Muslims & 5 \\
12. & Opinions & 5 \\
13. & Research & 5 \\
14. & Islam & 4 \\
15. & People & 4 \\
16. & Salman & 4 \\
17. & Authority & 3 \\
18. & Violence & 3 \\
19. & Terrorism & 3 \\
20 & Ruling & 1 \\
\hline
\end{tabular}

Table 12. Adjective Collocates Within 5 Words to the Left and Right of 'Terrorism

\begin{tabular}{lll}
\hline No & Keyword & NF \\
\hline 1. & International & 514 \\
2. & Global & 309 \\
3. & New & 230 \\
4. & Nuclear & 229 \\
5. & Other & 227 \\
6. & Domestic & 214 \\
7. & Islamic & 134 \\
8. & Political & 126 \\
9. & National & 125 \\
10. & American & 115 \\
11. & Military & 93 \\
12. & Middle & 86 \\
13. & Mass & 72 \\
14. & Islamist & 71 \\
15. & Palestinian & 68 \\
16. & Important & 67 \\
17. & Involved & 66 \\
18. & State-sponsored & 66 \\
19. & Foreign & 65 \\
20 & Joint & 61 \\
\hline
\end{tabular}

Table 13. Adjective Collocates Within 5 Words to the Left and Right of 'Terrorist'

\begin{tabular}{lll}
\hline No & Keyword & NF \\
\hline 1. & Other & 512 \\
2. & Suspected & 443 \\
3. & Islamic & 277 \\
4. & New & 252 \\
5. & International & 249 \\
6. & American & 246 \\
7. & Potential & 233 \\
8. & Foreign & 229 \\
9. & Palestinian & 217 \\
10. & Nuclear & 214 \\
11. & Military & 179 \\
\hline
\end{tabular}




\begin{tabular}{lll}
\hline 12. & Possible & 173 \\
13. & Alleged & 127 \\
14. & Muslim & 122 \\
15. & Domestic & 121 \\
16. & Major & 120 \\
17. & Known & 108 \\
18. & Middle & 101 \\
19. & Political & 99 \\
20 & Global & 98 \\
\hline
\end{tabular}

Table 14. Adjective Collocates Within 5 Words to the Left and Right of 'Radical'

\begin{tabular}{lll}
\hline No & Keyword & NF \\
\hline 1. & Free & 756 \\
2. & Islamic & 505 \\
3. & New & 375 \\
4. & Political & 252 \\
5. & Other & 211 \\
6. & Social & 179 \\
7. & American & 139 \\
8. & Economic & 138 \\
9. & Radical & 137 \\
10. & Islamist & 127 \\
11. & Muslim & 127 \\
12. & Religious & 100 \\
13. & Black & 86 \\
14. & Left & 83 \\
15. & Liberal & 82 \\
16. & Shiite & 82 \\
17. & Young & 80 \\
18. & Feminist & 76 \\
19. & Human & 70 \\
20 & Arab & 64 \\
\hline
\end{tabular}

Table 15. Noun Collocates Within 5 Words to the Left and Right of 'Radical'

\begin{tabular}{lll}
\hline No & Keyword & NF \\
\hline 1. & Change & 616 \\
2. & Groups & 377 \\
3. & Islam & 323 \\
4. & Changes & 322 \\
5. & Group & 265 \\
6. & Reform & 236 \\
7. & Movement & 174 \\
8. & Departure & 164 \\
9. & People & 164 \\
10. & Politics & 148 \\
11. & Party & 146 \\
12. & Transformation & 143 \\
13. & Cleric & 142 \\
14. & Islamists & 139 \\
15. & Time & 139 \\
16. & Way & 139 \\
17. & Ideas & 131 \\
18. & Right & 127 \\
19. & Idea & 126 \\
20 & Government & 126 \\
\hline
\end{tabular}


Table 16. Adjective Collocates Within 5 Words to the Left and Right of 'Radicalism'

\begin{tabular}{lll}
\hline No & Keyword & NF \\
\hline 1. & Islamic & 61 \\
2. & Political & 35 \\
3. & American & 23 \\
4. & Aristocratic & 22 \\
5. & Religious & 19 \\
6. & Black & 16 \\
7. & New & 15 \\
8. & Islamist & 12 \\
9. & Arab & 11 \\
10. & Left & 10 \\
11. & Right-wing & 9 \\
12. & Cultural & 8 \\
13. & Other & 8 \\
14. & Social & 8 \\
15. & Democratic & 7 \\
16. & Great & 7 \\
17. & Irish-American & 7 \\
18. & Different & 6 \\
19. & Muslim & 6 \\
20 & Extreme & 4 \\
\hline
\end{tabular}

Table 17. Noun Collocates Within 5 Words to the Left and Right of 'Radicalism'

\begin{tabular}{lll}
\hline No & Keyword & NF \\
\hline 1. & Labor & 22 \\
2. & Revolution & 15 \\
3. & Hotbed & 10 \\
4. & Other & 10 \\
5. & Rise & 9 \\
6. & World & 9 \\
7. & Conservatism & 8 \\
8. & Culture & 8 \\
9. & Notion & 7 \\
10. & Way & 7 \\
11. & Era & 6 \\
12. & Extremism & 6 \\
13. & History & 6 \\
14. & Kind & 6 \\
15. & Elections & 5 \\
16. & Government & 5 \\
17. & Terrorism & 4 \\
18. & Threat & 4 \\
19. & Fundamentalism & 3 \\
20 & Islam & 3 \\
\hline
\end{tabular}

Table 18. Adjective Collocates Within 5 Words to the Left and Right of 'Militant'

\begin{tabular}{lll}
\hline No & Keyword & NF \\
\hline 1. & Islamic & 587 \\
2. & Palestinian & 291 \\
3. & Muslim & 132 \\
4. & Other & 132 \\
5. & Islamist & 103 \\
6. & Israeli & 102 \\
7. & Black & 90 \\
8. & Taliban & 87 \\
9. & Pakistani & 85 \\
10. & Suspected & 81 \\
11. & New & 78 \\
\hline
\end{tabular}




\begin{tabular}{lll}
\hline 12. & Foreign & 63 \\
13. & Religious & 55 \\
14. & Shiite & 53 \\
15. & Political & 45 \\
16. & American & 44 \\
17. & Military & 43 \\
18. & Al-Qaida & 43 \\
19. & Afghan & 40 \\
20 & Arab & 37 \\
\hline
\end{tabular}

Table 19. Noun Collocates Within 5 Words to the Left and Right of 'Militant'

\begin{tabular}{lll}
\hline No & Keyword & NF \\
\hline 1. & Groups & 424 \\
2. & Islam & 131 \\
3. & Attacks & 120 \\
4. & Movement & 99 \\
5. & Forces & 91 \\
6. & Leader & 79 \\
7. & Government & 74 \\
8. & People & 64 \\
9. & Leaders & 61 \\
10. & Hamas & 60 \\
11. & Party & 58 \\
12. & Violence & 57 \\
13. & Army & 55 \\
14. & Organization & 53 \\
15. & Border & 52 \\
16. & War & 52 \\
17. & Soldiers & 51 \\
18. & Organizations & 49 \\
19. & Security & 48 \\
20 & Soldiers & 51 \\
\hline
\end{tabular}

Table 20. Adjective Collocates Within 5 Words to the Left and Right of 'Fundamentalist'

\begin{tabular}{lll}
\hline No & Keyword & NF \\
\hline 1. & Islamic & 474 \\
2. & Christian & 223 \\
3. & Muslim & 200 \\
4. & Religious & 178 \\
5. & Other & 72 \\
6. & Evangelical & 63 \\
7. & Radical & 56 \\
8. & Political & 48 \\
9. & Hindu & 38 \\
10. & American & 35 \\
11. & Protestant & 34 \\
12. & Conservative & 31 \\
13. & Modern & 28 \\
14. & New & 28 \\
15. & Southern & 25 \\
16. & Secular & 22 \\
17. & Jewish & 20 \\
18. & Arab & 19 \\
19. & Baptist & 19 \\
20 & Militant & 19 \\
\hline
\end{tabular}


Table 21. Noun Collocates Within 5 Words to the Left and Right of 'Fundamentalist'

\begin{tabular}{lll}
\hline No & Keyword & NF \\
\hline 1. & Groups & 125 \\
2. & Christian & 111 \\
3. & Movement & 84 \\
4. & Group & 83 \\
5. & Islam & 79 \\
6. & Church & 64 \\
7. & Muslims & 55 \\
8. & Government & 54 \\
9. & Evangelicals & 50 \\
10. & Leaders & 50 \\
11. & World & 49 \\
12. & People & 40 \\
13. & Power & 39 \\
14. & Party & 38 \\
15. & Movements & 37 \\
16. & Churches & 34 \\
17. & Forces & 32 \\
18. & Regime & 31 \\
19. & Religion & 31 \\
20 & Country & 30 \\
\hline
\end{tabular}

Table 22. Adjective Collocates Within 5 Words to the Left and Right of 'Fundamentalism'

\begin{tabular}{lll}
\hline No & Keyword & NF \\
\hline 1. & Islamic & 350 \\
2. & Religious & 161 \\
3. & Christian & 40 \\
4. & Muslim & 34 \\
5. & Radical & 34 \\
6. & Militant & 21 \\
7. & Political & 21 \\
8. & American & 19 \\
9. & Other & 15 \\
10. & Secular & 15 \\
11. & Central & 13 \\
12. & Biblical & 13 \\
13. & Arab & 12 \\
14. & Middle & 12 \\
15. & Protestant & 12 \\
16. & Jewish & 11 \\
17. & New & 11 \\
18. & Intransigent & 10 \\
19. & Different & 9 \\
20 & Modern & 8 \\
\hline
\end{tabular}

Table 23. Noun Collocates Within 5 Words to the Left and Right of 'Fundamentalism'

\begin{tabular}{lll}
\hline No & Keyword & NF \\
\hline 1. & Rise & 52 \\
2. & Islam & 31 \\
3. & Terrorism & 30 \\
4. & World & 22 \\
5. & Kind & 18 \\
6. & Religion & 17 \\
7. & Nationalism & 14 \\
8. & Term & 14 \\
9. & Threat & 14 \\
10. & History & 12 \\
11. & Side & 12 \\
\hline
\end{tabular}




\begin{tabular}{lll}
\hline 12. & Spread & 12 \\
13. & Forms & 10 \\
14. & People & 10 \\
15. & Politics & 10 \\
16. & Years & 10 \\
17. & Culture & 9 \\
18. & Faith & 9 \\
19. & War & 9 \\
20 & Christianity & 8 \\
\hline
\end{tabular}

\section{Copyrights}

Copyright for this article is retained by the author(s), with first publication rights granted to the journal.

This is an open-access article distributed under the terms and conditions of the Creative Commons Attribution license (http://creativecommons.org/licenses/by/3.0/). 